\title{
Impact of a recent tobacco tax reform in Argentina
}

\author{
Martín González-Rozada (1) 1,2
}

'Department of Economics, Universidad Torcuato Di Tella, Buenos Aires, Argentina ${ }^{2}$ Universidad Torcuato Di Tella, Buienos Aires, Argentina

\section{Correspondence to}

Martín González-Rozada, Economics, Universidad Torcuato Di Tella, Buenos Aires 1428, Argentina; mrozada@utdt.edu

Received 26 June 2019 Revised 5 December 2019 Accepted 13 December 2019 Published Online First 25 August 2020

\section{Check for updates}

(c) Author(s) (or their employer(s)) 2020. No commercial re-use. See rights and permissions. Published by BMJ.

To cite: González-Rozada M. Tob Control

2020:29:5300-s303.

\section{ABSTRACT}

The literature on policies for the control of the tobacco epidemic suggests that increasing excise taxes on the consumption of tobacco products is the most costeffective policy. Cigarette tax structure in Argentina is very complex. All the tax bases for cigarette consumption taxes are related and, therefore, any modification of a tax affects the collection of the rest of the taxes. This is important given that funds raised by one of the taxes, the Special Tobacco Fund (FET), are allocated among the tobacco provinces according to the value of tobacco production. These provinces oppose in the congress to any reform that increase taxes on cigarette consumption that negatively affects these funds. In May 2016, the government decided to increase the rate of one of the taxes, the internal tax, from $60 \%$ to $75 \%$. We study the impact on cigarettes' demand price elasticity, consumption and tax revenues of this tobacco tax reform. Using an Error Correction Model, we estimate short-run and long-run demand price and income elasticities. We find that the tax reform of May 2016 induced an increase in the magnitude, in absolute value, of the short-run demand price elasticity and at the same time increased the funds collected by the FET. We simulate the effects of the tax reform over the government revenues and per-capita consumption of cigarettes showing that additional increments in taxes would increase revenues and diminish consumption of cigarettes.

\section{INTRODUCTION}

The literature on policies for tobacco control suggests that increasing excise taxes on the consumption of tobacco products is the most cost-effective policy. The reason is that increasing taxes causes the prices of tobacco products to increase. This makes the different tobacco products less accessible, thus reducing initiation, prevalence and consumption of tobacco. In addition, because the demand for tobacco is inelastic, higher taxes generate increases in tax revenues. See Gajalakshmi et $a{ }^{1}{ }^{1}$ Jha and Chaloupka ${ }^{2}$, Ranson et $a l^{3}$ among others for international evidence. See González-Rozada ${ }^{4}$ GonzálezRozada and Rodríguez-Iglesias ${ }^{5}$, Rodríguez-Iglesias et $a l^{6}$ for evidence for Argentina.

The tax structure on cigarette consumption in Argentina is very complex including four ad-valorem taxes. One of the taxes, the Special Tobacco Fund (FET), acts as a subsidy to the provinces that produce tobacco. Therefore, these provinces oppose in the congress to any tax reform that negatively affects these funds. In May 2016, the government decided to increase the rate of one of the taxes, the internal tax, from $60 \%$ to $75 \%$. In this paper, we study the impact on cigarettes' demand price elasticity, consumption and tax revenues of this tobacco tax reform. Using an Error Correction Model, we estimate short-run and long-run demand price and income elasticities. Then, using these estimations, we simulate the impact of the tax reform by increasing the rate of internal taxes on consumption of cigarettes and government revenue. The rest of the work is organised as follows. Section 2 describes the tax structure of cigarettes in Argentina and presents the tax reform and its impact on the tax share on prices, retail price, FET and government tax revenue. Section 3 describes the data used in the estimation of the demand function of cigarettes and studies the underlying statistical properties of retail price, real income and consumption of cigarettes. Section 4 introduces the methodology used to estimate demand price and income elasticities. Section 5 shows the main results of the paper and Section 6 concludes the work.

\section{TAX STRUCTURE OF CIGARETTES IN ARGENTINA}

The tax structure on cigarette consumption in Argentina is very complex. Federal taxes affecting cigarettes are four ad-valorem taxes: the additional emergency tax (IAE), the value added tax (VAT), the FET and the internal tax (II). The tax base of each one is different. Table 1 shows tax rates, tax base and the tax share on the retail price of each ad-valorem tax before the reform.

The tax share on prices before the tax reform of May 2016 was $68.6 \%$. The average retail price in April 2016 was almost AR $\$ 26$ per pack of 20 cigarettes (AR\$3.1 in real terms) and internal taxes represented $47 \%$ of that retail price. This structure implies than changing the tax rate of one of the taxes affects the tax base of the other taxes. This is important because, in practice, one of the taxes, the FET, acts as a subsidy to tobacco producers. The main objective of the FET is to guide, coordinate and supervise the actions tending to achieve the modernisation, reconversion, complementation and diversification of the tobacco areas, both in the primary production and in the associated agroindustrial chain. The funds raised by the FET are allocated among the tobacco provinces according to the value of tobacco production. The Ministry of Agriculture of the Nation is the enforcement authority of the FET. It has in its functions to fix the price of the different varieties of tobacco and transfer the collection of the FET to the provinces so that they make cash the payment of the surcharge to the producers. That is, the FET acts as a subsidy to tobacco producers and the tobacco industry in particular.

Usually, those who oppose increasing taxes on tobacco products use the FET as an argument against it by saying that increment in taxes will reduce the FET funds. It is important then, for 


\begin{tabular}{|c|c|c|c|}
\hline \multicolumn{4}{|c|}{ Table 1} \\
\hline Tax & Tax base & Tax rate & Tax share on RP \\
\hline IAE & RP & $7 \%$ & $7.0 \%$ \\
\hline VAT & RP - IAE - II - FET & $21 \%$ & $6.6 \%$ \\
\hline FET & RP - IAE - VAT & $8.35 \%$ & $7.8 \%$ \\
\hline II & RP - IAE - VAT - FET & $60 \%$ & $47.2 \%$ \\
\hline Total & & & $68.6 \%$ \\
\hline
\end{tabular}

ACigarettes Tax Structure

FET, Special Tobacco Fund; IAE, additional emergency tax; II, internal tax; RP, retail price; VAT, value added tax.

policy reasons, to show evidence that this is not the case when increasing internal taxes.

\section{The tax reform}

In May 2016, Argentina established an increase in the rate of II on cigarettes from $60 \%$ to $75 \%$. After this reform, the tax share on retail price increased and reached almost $80 \%$. II represented almost $61 \%$ of the average retail price of almost AR $\$ 50$ per pack of 20 cigarettes (AR\$4.5 in real terms). FET tax share on retail price decreased slightly from $7.8 \%$ to $7.7 \%$ but because average real retail price of a pack of 20 cigarettes increased almost 50\%, from AR $\$ 3.1$ to AR $\$ 4.5$, FET funds increased.

The response of the tobacco industry to the tax reform was to increase average retail prices of cheapest brands $40 \%$ in the month after the reform while for the most expensive brands, they incremented average retail prices by $50 \%$. This strategy had to do with the cigarette consumption market in Argentina, where the great majority of smokers consume the most expensive brands (for data source of response of the industry and structure of consumption of cigarettes see next section).

After the second quarter of 2016, there was a clear increase in the collection of internal taxes. Before the tax reform, tax revenues from II were around 4500 million of constant AR\$, while after the reform these revenues were almost 6000 million.

Figure 1 shows the tax collection, in millions of constant pesos of the fourth quarter of 2017, coming from the FET before and after the implementation of the reform of May 2016 (marked in the figure by the dotted vertical line). As can be observed, after the tax reform, the tax collection from the FET increased throughout the period analysed. Before the reform FET revenues were around AR $\$ 750$ million and jumped to more than AR $\$ 850$ million just after the reform. The main reason for this was the tax base increase due to the increment in retail prices.

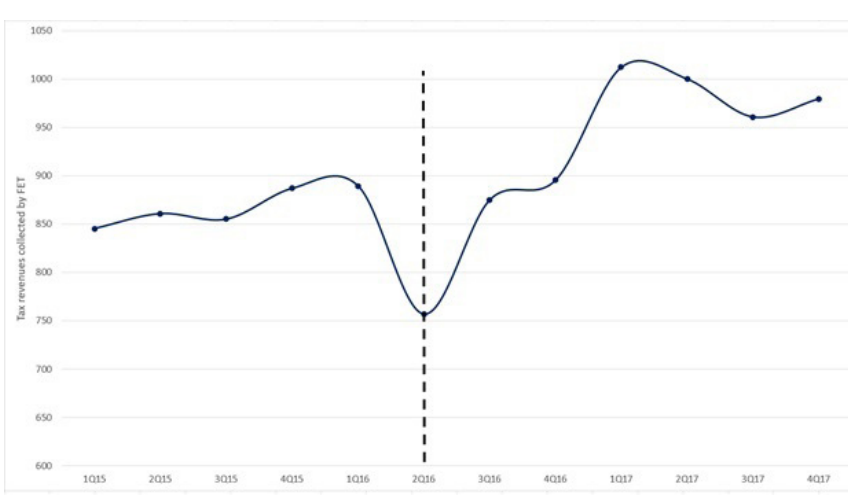

Figure 1 Tax revenue collected by the FET. Author elaboration. FET, Special Tobacco Fund.
This evidence shows that it is possible to increase taxes on the consumption of cigarettes without affecting the FET funds. As mentioned above, affecting the FET funds is a political concern when there is a proposal to increment taxes on cigarettes.

\section{DATA AND STATISTICAL PROPERTIES}

We use monthly data from January 2005 to June 2018 for consumption (approximated by the total sales of packages of 20 cigarettes), average real retail price of cigarettes and real income of the population, represented by the average remuneration of registered workers of the private sector published by the Ministry of Labour, Employment and Social Security (Data are available online here: https://www.agroindustria.gob.ar/sitio/ areas/tabaco/estadisticas; https://www.trabajo.gob.ar/left/estadisticas/descargas/SIPA/AnexoEstadistico.xlsx). To specify the demand function for cigarettes, we first needed to find the statistical properties of these variables. Using the Augmented DickeyFuller test, ${ }^{7}$ we show that all three variables, consumption, real price and real income, have individually a unit root. Then, using the Johansen Trace test, ${ }^{8}$ we show that the three variables are cointegrated.

\section{METHODOLOGY FOR ESTIMATING THE DEMAND PRICE ELASTICITY OF CIGARETTES}

Cointegration implies that the tobacco demand function can be specified with a model that takes into account not only the relationship between the variables in the short-run but also in the long-run. Using an error correction model, the long-run relationship among consumption of cigarettes, real retail price and real income is:

$$
c_{t}=k_{i}+\lambda_{1} p_{t}+\lambda_{2} y_{t}+u_{t}
$$

Where $c_{t}$ is the natural log of consumption, $p_{t}$ is the natural $\log$ of real retail price, $y_{t}$ is the natural $\log$ of real income and $u_{t}$ is an error term. $\lambda_{1}$ is the demand price elasticity and $\lambda_{2}$ is the real income elasticity. Equation (1) is the long-run equilibrium relationship.

In the short-run, the variables may not be in the steady state; therefore, we specify the dynamics of the short-run relationship using $r$ lags in equation (2).

$$
\begin{aligned}
\Delta c_{t}= & \delta+(\alpha-1)\left\{c_{t-1}-\frac{k_{i}^{*}}{1-\alpha}-\frac{\beta}{1-\alpha} p_{t-1}-\frac{\gamma}{1-\alpha} y_{t-1}\right\} \\
& +\sum_{j=1}^{r-1} \alpha_{j}^{*} \Delta c_{t-j}+\beta_{0} \Delta p_{t}+\sum_{j=1}^{r-1} \beta_{j}^{*} \Delta p_{t-j}+\gamma_{0} \Delta y_{t} \\
& +\sum_{j=1}^{r-1} \gamma_{j}^{*} \Delta y_{t-j}+\theta_{0} \Delta p_{t} D_{2016}+\sum_{j=1}^{r-1} \theta_{j} \Delta p_{t-j} D_{2016}+\epsilon_{t}
\end{aligned}
$$

Where $\delta, \alpha, \beta, \gamma, \alpha_{j}^{*}, \beta_{0}, \beta_{j}^{*}, \gamma_{0}, \gamma_{j}^{*}, \theta_{0}, \theta_{j}$ and $k_{i}^{*}$ are the parameters of the model and $\varepsilon_{t}$ is a stationary error term. The value of $r$ determines the number of months involved in the long-run concept of the model. The term in levels between braces represents the solution of long-run equilibrium (1), while all the variables in first differences measure the short-run dynamics. Some of the parameters in (2) have an interpretation in terms of the short-run elasticities of cigarette consumption. In particular, $\beta_{0}$ is the short-run demand price elasticity and $\gamma_{0}$ is the short-run real income elasticity. To capture the impact of the tax reform, we introduced a binary variable, $D_{201}$, adopting the unity value since May 2016 when the reform was applied onwards. This indicator variable interacts with the price variables in the short-run specification (2). Then, the impact of the reforms on the short-run demand price elasticity is measured by: $\beta_{0}+\theta_{0}$. For a detailed description of the model see Annex two in González-Rozada. ${ }^{9}$ 


\begin{tabular}{|c|c|c|c|c|}
\hline \multicolumn{5}{|c|}{$\begin{array}{l}\text { Dependent variable: } \log \text { (consumption of cigarettes) } \\
\text { Estimation method: ordinary least squares } \\
\text { Sample: 2005:01 2018:06 }\end{array}$} \\
\hline Variable & Coefficient & SE & t-statistic & $P$ value \\
\hline Log (real retail price) & -0.441378 & 0.041681 & -10.58949 & 0.0000 \\
\hline Log (real income) & 0.127087 & 0.032331 & 3.93081 & 0.0001 \\
\hline Christmas bonus & -0.113140 & 0.023840 & -4.745777 & 0.0000 \\
\hline Intercept & 9.548160 & 0.254803 & 37.47268 & 0.0000 \\
\hline Adjusted R squared & 0.508313 & & & \\
\hline F-statistic & 56.48126 & & & \\
\hline$P$ value & 0.000000 & & & \\
\hline
\end{tabular}

Author estimations.

We estimate the ECM using the Engle-Granger methodology. ${ }^{10}$ This is a two-stage estimate. First, we estimate the longterm equilibrium relationship (1) and then we estimate the ECM (2) to obtain the short-run effects.

\section{RESULTS}

Table 2 shows the estimation of equation (1) including a dummy variable for the Christmas bonus. The long-run demand price elasticity is -0.441 , while the long-run real income elasticity is 0.127 . These values imply that, in the long-run, a $10 \%$ increase in the real retail price reduces cigarette consumption by $4.41 \%$ and a $10 \%$ increase in real income increases the consumption of cigarettes by $1.27 \%$. All estimations are statistically significant at usual levels of significance.

Table 3 shows the estimation of the short-term dynamics, including the effect of the tax increase from May 2016. Z(t-1) represents the estimation of term in levels between braces of equation (2). The variable $D_{2016}$ is a binary variable adopting the unity value since the month of May 2016 when the tax reform was implemented. As can be seen in the table, the short-run demand price elasticity without the effect of the reform is -0.91 while, as a result of the reform of May 2016, this value is -1.38 .
These results suggest that, in the short-run before the reform, a $10 \%$ increase in real retail price induced a $9 \%$ decrease in consumption, while after the tax reform the same increase in real retail price produced a decrease in consumption of cigarettes of around $14 \%$. The tax reform induced a huge increase in retail price and this, in turn, produced a large fall in consumption for a few months after the reform. These sudden changes are captured by the increment, in absolute magnitude, of the short-run demand price elasticity.

\section{Simulation of results}

To analyse the impact of the reform of May 2016 on cigarette consumption and tax collection, we perform a simulation exercise. In this exercise, we use the long-run price elasticity of -0.44 presented in table 1 and increase the internal tax rate sequentially. In this way, we can see the impact of the fiscal reform. The parameters used for the simulation exercise are:

Consumption of cigarettes: 177056579 packages

Average retail price: AR $\$ 25.88$ per package

Tax on cigarettes: AR $\$ 20.65$ per package

Government revenue for taxes on cigarettes: AR\$3 658275 567

Exchange rate: 14.25 AR \$ per dollar

Population (over 15 years old): 31452302

Consumption per capita: 67.53 packages per year

Figure 2 shows the changes in the government's tax revenue. The vertical line shows the tax increase of 15 percentage points produced by the fiscal reform, the figure shows that there is enough room to increase the internal tax rate on cigarette consumption and still increase government's tax revenue. For example, if the government decided to increase the internal tax rate an additional three percentage points, it would increase tax revenues around US\$200 million.

Figure 3 shows the effects of the tax reform on the per capita consumption of cigarettes. As in figure 2 , the vertical line shows the implemented fiscal reform, an increase in the internal tax rate from $60 \%$ to $75 \%$. The figure shows that this increment

Table 3 Short-run elasticity estimation

\begin{tabular}{|c|c|c|c|c|}
\hline $\begin{array}{l}\text { Dependent variable: } \Delta \text { Log (cc } \\
\text { Estimation method: ordinary } \\
\text { Sample: 2005:01 2018:06 }\end{array}$ & & & & \\
\hline Variable & Coefficient & SE & t-statistic & $P$ value \\
\hline$\Delta \log ($ real retail price $)$ & -0.911623 & 0.163823 & -5.564695 & 0.0000 \\
\hline$\Delta \log \left(\right.$ real retail price $\left.e_{t-1}\right)$ & -0.279836 & 0.170829 & -1.638103 & 0.1036 \\
\hline$\Delta \log \left(\right.$ real income $\left.e_{t-1}\right)$ & 0.26583 & 0.033446 & 7.821132 & 0.0000 \\
\hline$\Delta \log \left(\right.$ real income $\left.e_{t-2}\right)$ & 0.108007 & 0.028520 & 3.787008 & 0.0002 \\
\hline Christmas bonus & -0.241369 & 0.021381 & -11.28871 & 0.0000 \\
\hline$\Delta \log \left(\right.$ Consumption $\left._{t-1}\right)$ & -0.373577 & 0.070983 & -5.262917 & 0.0000 \\
\hline$\Delta \log \left(\right.$ Consumption $\left._{t-2}\right)$ & -0.328439 & 0.05735 & -5.726882 & 0.0000 \\
\hline Adjusted R squared & 0.803356 & & & \\
\hline F-statistic & 50.65259 & & & \\
\hline$P$ value & 0.000000 & & & \\
\hline
\end{tabular}

Author estimations. 


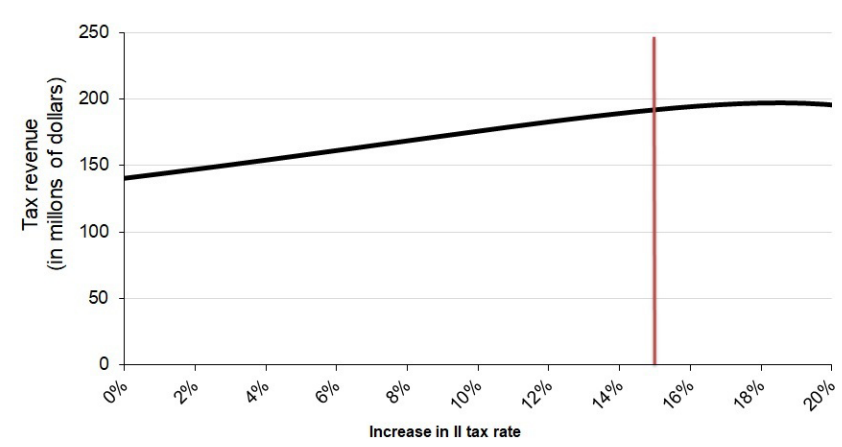

Figure 2 Government revenue for each internal tax increase Author elaboration.

in the internal tax rate induced a fall in the average per capita consumption of cigarettes from 68 to around 50 packs per year. The figure also shows that further increases in the internal tax rate would reduce the average per capita consumption of cigarettes.

\section{CONCLUSION}

We studied the impact on demand price elasticity, the FET, cigarette consumption and tax collection of a recent tax reform in Argentina. This reform increased the rate of internal taxes from $60 \%$ to $75 \%$ and this, in turn, increased the government revenues collected from II about $40 \%$ by the end of 2016 . We provided evidence that the increment in the rate of internal taxes produced an increment in the revenue collected by the FET. We estimate an ECM, obtaining short-run and long-run demand price elasticities. We found a long-run elasticity of -0.441 , suggesting that a $10 \%$ increase in the real retail price of cigarettes would decrease consumption by around $4.4 \%$. The estimation of the short-run demand price elasticity was -0.911 without the tax reform, whereas if we consider the reform, this short-run elasticity increases in absolute value to -1.385 . Using the estimation of the demand price elasticity, we simulate the impact of the tax reform by increasing the rate of internal

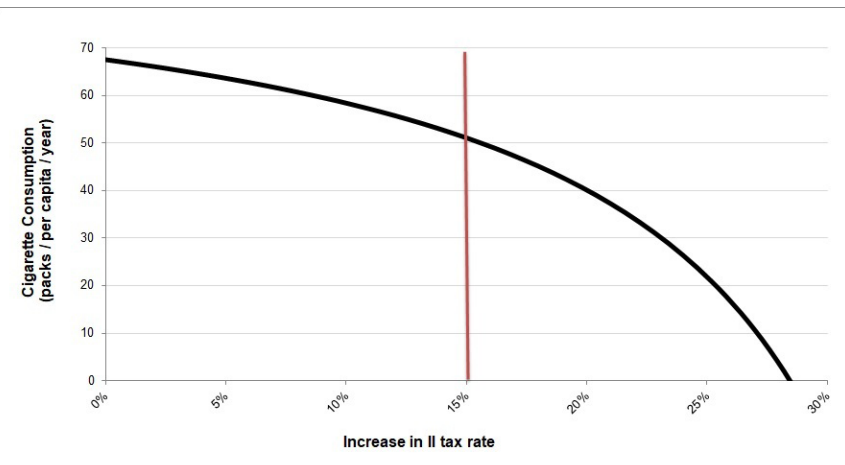

Figure 3 Average annual consumption per capita for each internal tax increase Author elaboration. taxes on consumption and government revenue, finding that it is possible to increase even more this tax rate and increase revenues and decrease consumption of cigarettes.

\section{What this paper adds}

- This paper shows how a tobacco tax reform affects cigarette's demand price elasticity, tobacco consumption and government revenues in the context of a complex cigarettes tax structure.

- Argentina cigarette's tax structure include four ad-valorem taxes. One of the taxes, the Special Tobacco Fund (FET), acts as a subsidy to the provinces that produce tobacco. Therefore, these provinces oppose in the congress to any tax reform that negatively affects these funds. We show that the tax reform of May 2016, that increase the rate of one of the taxes, the internal tax, from $60 \%$ to $75 \%$ induced an increment in the funds raised by the FET.

- Using the estimation of the demand price elasticity, we simulate the impact of the tax reform by increasing the rate of internal taxes on consumption and government revenue, finding that it is possible to increase even more this tax rate and increase revenues and decrease consumption of cigarettes.

\section{Twitter Martín González-Rozada @MartinGRozada}

Contributors I wrote the paper and made all estimations in it.

Funding The authors have not declared a specific grant for this research from any funding agency in the public, commercial or not-for-profit sectors.

Competing interests None declared.

Patient consent for publication Not required.

Provenance and peer review Not commissioned; externally peer reviewed.

Data availability statement Data are available in a public, open access repository. All data relevant to the study are included in the article or uploaded as supplementary information.

\section{ORCID iD}

Martín González-Rozada http://orcid.org/0000-0001-7460-7882

\section{REFERENCES}

1 Gajalakshmi C, Jha P, Ranson K. Global patterns of smoking and smoking attributable mortality patterns. In: Jha P, Chaloupka F, eds. Tobacco control in developing countries. Oxford: Oxford University Press, 2000: 11-39.

2 Jha P, Chaloupka F. Tobacco control in developing countries. Oxford: Oxford University Press, 2000.

3 Ranson $\mathrm{K}$, Jha P, Chaloupka F, et al. Effectiveness and cost-effectiveness of price increases and other tobacco-control policies. In: Jha P, Chaloupka F, eds. Tobacco control in developing countries. Oxford: Oxford University Press, 2000.

4 González-Rozada M. Economía del control del tabaco en Los países del Mercosur Y estados asociados. Argentina, 1996-2004. Washington, DC: PAHO, 2006.

5 González-Rozada M, Rodríguez-Iglesias G. Análisis de la demanda de cigarrillos en Argentina. Buenos Aires: Interamerican Heart Foundation of Argentina, 2014.

6 Rodríguez-Iglesias G, Schoj V, Chaloupka F, et al. Analysis of cigarette demand in Argentina: the impact of price changes on consumption and government revenues. Salud Publica Mex 2017;59:95-101.

7 Dickey $D$, Fuller W. Distribution of the estimators for autoregressive time series with a unit root. J Am Stat Assoc 1979;6:427-31.

8 Johansen S. Estimation and hypothesis testing of cointegration vectors in Gaussian vector autoregressive models. Econometrica 1991;59:1551-80.

9 González-Rozada M. Economía del control del Tabaco en Los países del MERCOSUR Y Estados Asociados: Argentina 1996-2004. Washington, D.C: OPS, 2006. ISBN: 9275 32625 8. http://www1.paho.org/Spanish/AD/SDE/RA/Tab_Mercosur_ARG.pdf?ua=1

10 Engle RF, Granger CWJ. Co-Integration and error correction: representation, estimation, and testing. Econometrica 1987;55:251-76. 